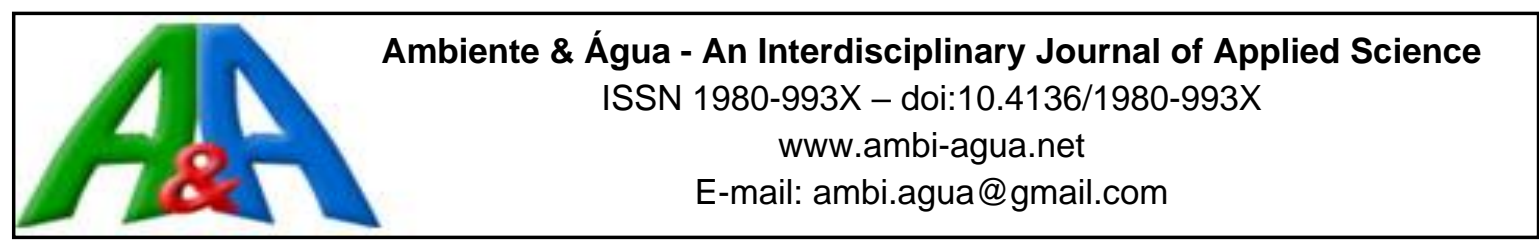

\title{
Toxicity of pesticides with fungicide and fungicide + insecticide effects to Eisenia andrei
}

ARTICLES doi:10.4136/ambi-agua.2493

Received: 06 Nov. 2019; Accepted: 12 Mar. 2020

\section{Isabela Aparecida Giordani1 ${ }^{1 D}$; Eduarda Busatta ${ }^{1}$; \\ Luís Carlos Iuñes de Oliveira Filho ${ }^{2}$; Dilmar Baretta ${ }^{3}$; Camila Kissmann ${ }^{4}{ }^{\circledR}$; Carolina Riviera Duarte Maluche Baretta ${ }^{1 *}$ (iD}

\footnotetext{
${ }^{1}$ Área de Ciências Exatas e Ambientais. Universidade Comunitária da Região de Chapecó (UNOCHAPECÓ), Servidão Anjo da Guarda, n 295D, CEP: 89809-900, Chapecó, SC, Brazil.

E-mail: isabelagiordani@unochapeco.edu.br, eduarda.busatta@unochapeco.edu.br

${ }^{2}$ Departamento de Solos. Faculdade de Agronomia Eliseu Maciel. Universidade Federal de Pelotas (UFPel), Avenida Eliseu Maciel, S/N, CEP: 96160-000, Capão do Leão, RS, Brazil. E-mail: iunes1981@ gmail.com ${ }^{3}$ Departamento de Zootecnia. Universidade do Estado de Santa Catarina (UDESC), Rua Beloni Trombeta Zanin, n 680E, CEP: 89815-630, Chapecó, SC, Brazil. E-mail: dilmar.baretta@udesc.br

${ }^{4}$ Departamento de Botânica. Universidade Estadual Paulista "Júlio de Mesquita Filho" (UNESP), Rua Antonio Celso Wagner Zanin, n 250, CEP: 18618-689, Botucatu, SP, Brazil. E-mail: camilakissmann@ gmail.com *Corresponding author. E-mail: carolmaluche@unochapeco.edu.br
}

\begin{abstract}
Pesticides are widely used in the agricultural sector to control and prevent pests and diseases. The use of these products can adversely affect non-target organisms that have a significant role in the soil, such as earthworms. This study evaluated the toxicity of the commercial formulation of the fungicide Comet ${ }^{\circledR}$ (active ingredient - a.i. pyraclostrobin) at concentrations of $0.08,0.17,0.35,0.70,1.40$ and $2.80 \mathrm{mg}$ of the commercial formulation $\mathrm{kg}^{-1}$ soil and the fungicide + insecticide Standak $®$ Top (a.i. pyraclostrobin + thiophanate-methyl + fipronil) at concentrations of $0.05,0.10,0.20,0.60,1.20$ and $2.40 \mathrm{mg}$ of the commercial formulation $\mathrm{kg}^{-1}$ soil, plus the control treatment, to Eisenia andrei in Tropical Artificial Soil (TAS) by means of standardized tests.
\end{abstract}

Keywords: artificial soil, earthworms, ecotoxicology, fungicide, insecticide.

\section{Toxicidade de agrotóxicos de efeito fungicida e fungicida + inseticida em Eisenia andrei}

\section{RESUMO}

Os agrotóxicos são amplamente utilizados no setor agrícola para o controle e prevenção contra pragas e doenças. O uso desses produtos é capaz de afetar de maneira negativa organismos não-alvos de papel significante no solo, como as minhocas. O presente trabalho teve como objetivo avaliar a toxicidade da formulação comercial do fungicida Comet $^{\circledR}$ (ingrediente ativo - i.a. piraclostrobina) nas concentrações: 0,$08 ; 0,17 ; 0,35 ; 0,70 ; 1,40$ e 2,80 $\mathrm{mg}$ da formulação comercial $\mathrm{kg}^{-1}$ solo e do fungicida + inseticida Standak ${ }^{\circledR}$ Top (i.a. piraclostrobina + tiofanato metílico + fipronil) nas concentrações: 0,$05 ; 0,10 ; 0,20 ; 0,60 ; 1,20$ e 2,40 mg mg da formulação comercial $\mathrm{kg}^{-1}$ solo, acrescido do tratamento controle, sobre a espécie Eisenia andrei em Solo Artificial Tropical (SAT), por meio de ensaios padronizados. 
As concentrações dos produtos testados não foram suficientes para causar a letalidade dos organismos. Entretanto, nas primeiras concentrações de ambos os produtos $\left(0,08\right.$ e $0,05 \mathrm{mg} \mathrm{kg}^{-}$ ${ }^{1}$ solo) foram observados efeitos de redução nas taxas reprodutivas dos organismos, com valor de $\mathrm{CE}_{50} 4,51 \mathrm{mg} \mathrm{kg}^{-1}$ solo $(<0,05-20,94)$ para a formulação comercial do produto de efeito fungicida + inseticida. Os efeitos de redução nas taxas de reprodução podem afetar a perpetuação desses organismos no ecossistema solo à longo prazo, afetando processos importantes como a decomposição de matéria orgânica e ciclagem de nutrientes.

Palavras-chave: ecotoxicologia, fungicida, inseticida, minhocas, solo artificial.

\section{INTRODUCTION}

Pesticides are used on a large scale worldwide in the agricultural and forestry sector and represent an important tool to control pests and diseases. They have been fundamental to maintaining high levels of food production. In 2017, the total amount of active ingredients sold in Brazil was approximately 540,000 tons (IBAMA, 2019) and the relative consumption of pesticides was $5.95 \mathrm{~kg} \mathrm{ha}^{-1}$ (FAO, 2019), as a result of agricultural production mainly focused on exports of commodities (Carneiro et al., 2015). Fungicides and insecticides are widely used pesticides in the agricultural sector, corresponding to $13.35 \%$ and $10.43 \%$ of the domestic market (IBAMA, 2019). These products are commonly marketed with formulations of multiple mixtures of active ingredients, and the actual impact caused by these combinations is still littleknown, especially with respect to the possible synergistic effects between them (Yang et al., 2017).

Several products are indicated for agricultural crops. Among them, pyraclostrobin and thiophanate-methyl are the active ingredients of some fungicides found in pesticides such as Comet $^{\circledR}$ (pyraclostrobin) and Standak ${ }^{\circledR}$ Top (fipronil + pyraclostrobin + thiophanate-methyl). Pyraclostrobin is a systemic fungicide belonging to the chemical group of strobilurins, recommended for agricultural and forestry crops, such as soybean and eucalyptus (EC, 2004; Brasil, 2020), whereas thiophanate-methyl is a systemic and contact fungicide belonging to the benzimidazole group, intended for agricultural crops (EC, 2005; Brasil, 2020). Fipronil is an insecticide of contact and ingestion, belonging to the chemical group of the pyrazoles, indicated for an extensive range of applications from plants to animals (EC, 2011; Brasil, 2020). Studies demonstrating the ecotoxicological potential of pesticides on non-target species, such as bees, earthworms and collembolans, include the death of these individuals, possibly leading to a population decline, even at recommended or very low concentrations (Pitombeira de Figueirêdo et al., 2019; Sánchez-Bayo et al., 2016; Yang et al., 2017).

Improper use of pesticides, often not complying with the manufacturers' recommendations and including sub- and super-doses, as well as an inadequate number of applications (Fusaro et $a l ., 2018$ ), are harmful to the community of soil organisms. In general, it has been estimated that only about $0.1 \%$ of the pesticides reach the target organisms (Carriger et al., 2006) and are considered important sources of soil, water and air contamination, and most of them do not only reach the target organism, they also affect other non-target organisms (Niti et al., 2013), such as earthworms. Earthworms are an essential component of terrestrial ecosystems, which contribute significantly to the functioning of the soil, providing important services, direct and indirect, contributing to the dynamics and fertility of the soil ecosystem (Chevillot et al., 2017) and they accumulate toxic substances, which may affect trophic chains (Yang et al., 2017). The species Eisenia andrei is considered representative of soil fauna, ideal for use in ecotoxicological assays, through tests of acute toxicity (lethality), chronic toxicity (survival and reproduction) and alterations in the biomass of the individuals, as it is sensitive to various chemicals and substances (OECD, 1984). 
Some studies have evaluated the ecotoxicological potential of a wide range of substances on earthworms (Chevillot et al., 2017; Rico et al., 2016). Sublethal and subchronic effects, which include reduction in reproductive rates and damage to the DNA of earthworms after exposure to the active ingredient fipronil in the form of a veterinary product and in pesticide formulations with only one active ingredient (Alves et al., 2013; Zortéa et al., 2018) and with the active ingredient pyraclostrobin (Ma et al., 2019) have already been reported. However, no other studies were found testing the effect of such commercial formulations evaluated in the present study in survival and reproduction toxicity tests. The present study evaluated the ecotoxicological effect of two pesticides, one with fungicide and one with fungicide + insecticide effects, widely used in agricultural crops and reforestation, on $E$. andrei by means of standardized tests of survival and reproduction using tropical artificial soil.

\section{MATERIALS AND METHODS}

\subsection{Test organisms}

The laboratory cultivation of earthworms of the species Eisenia andrei (Lumbricidae) followed the guidelines of ISO 11268-2 (ISO, 1998). The organisms were kept in plastic boxes with opening on the top to facilitate respiration, in a culture medium consisting of a mixture of two parts of dry equine manure (free of antibiotics and pesticides) sieved to $2 \mathrm{~mm}$, one part of coconut fiber powder and $10 \%$ of total dry weight of the two components (manure and fiber) of fine sand (90/100 granulometry). The $\mathrm{pH}$ of the medium was corrected to values between $6.0 \pm 0.5$ with addition of calcium carbonate $\left(\mathrm{CaCO}_{3}\right)$, and the earthworms were fed with fine oat flakes every week. The organisms were cultivated and the tests were conducted in a controlled environment with temperature of $20 \pm 2^{\circ} \mathrm{C}$ and photoperiod of 12:12 h (light:dark).

\subsection{Test soil}

The tests were conducted using the Tropical Artificial Soil (TAS), adapted to tropical conditions, consisting of a mixture of $75 \%$ of fine industrial sand, $20 \%$ of kaolinite clay and $5 \%$ of dried and sieved coconut fiber (Garcia, 2004). Soil moisture was corrected at the beginning of the test to $60 \%$ of the maximum water holding capacity (WHC), and $\mathrm{pH}$ was adjusted to $6.0 \pm 0.5$ with the addition of $\mathrm{CaCO}_{3}$. The physicochemical parameters of the TAS were determined according to the methodology described by Tedesco et al. (1995) and Embrapa (2011). The results of the TAS characterization were: clay $=13.8 \%$; sand $=73.1 \%$; cation exchange capacity $=30.09 \mathrm{cmol}_{\mathrm{c}} \mathrm{dm}^{-3} ; \mathrm{pH}\left(\mathrm{H}_{2} \mathrm{O}\right)=5.6$; organic matter $=5.0 \% ; \mathrm{P}=8.2 \mathrm{mg} \mathrm{dm}^{-}$ ${ }^{3} ; \mathrm{K}=488 \mathrm{mg} \mathrm{dm}^{-3} ; \mathrm{Ca}=0.6 \mathrm{mg} \mathrm{dm}^{-3} ; \mathrm{Mn}<2.5 \mathrm{mg} \mathrm{dm}^{-3} ; \mathrm{Cu}=0.4 \mathrm{mg} \mathrm{dm}^{-3} ; \mathrm{Zn}=1.3 \mathrm{mg} \mathrm{dm}^{-}$ 3; $\mathrm{Fe}>5.0 \mathrm{~g} \mathrm{dm}^{-3} ; \mathrm{Al}=0.8 \mathrm{cmol}_{\mathrm{c}} \mathrm{dm}^{-3}$.

\subsection{Test substances and concentrations}

The treatments consisted of increasing concentrations of the commercial formulations of the fungicide Comet $^{\circledR}$, containing Methyl N-\{2-[1-(4-chlorophenyl)-1H-pyrazol-3-yloxy methyl] phenyl $\}$ (N-methoxy) carbamate (pyraclostrobin) at $250 \mathrm{~g} \mathrm{~L}^{-1}(25 \% \mathrm{~m} / \mathrm{v})$, and the fungicide + insecticide Standak ${ }^{\circledR}$ Top, containing Methyl N-\{2-[1-(4-chlorophenyl)-1Hpyrazol-3-yloxy methyl] phenyl (N-methoxy) Carbamate (pyraclostrobin) at $25 \mathrm{~g} \mathrm{~L}^{-1}(2.5 \%$ $\mathrm{m} / \mathrm{v}$ ), Dimethyl 4,4'-(o-phenylene)bis(3-thio allophanate) (thiophanate-methyl) at $225 \mathrm{~g} \mathrm{~L}^{-1}$ $(22.5 \% \mathrm{~m} / \mathrm{v})$ and (RS)-5-amino-1-(2,6-dichloro- $\alpha, \alpha, \alpha$-trifluoro-p-tolyl)-4-trifluoromethyl sulfinyl pyrazole-3-carbonitrile (fipronil) at $250 \mathrm{~g} \mathrm{~L}^{-1}(25 \% \mathrm{~m} / \mathrm{v})$, applied to the TAS.

For each test substance, a gradient of laboratory-spiked soils, with increasing concentrations of commercial formulations of the Comet ${ }^{\circledR}$ and Standak ${ }^{\circledR}$ Top, was achieved. Each gradient of spiked soils was prepared with a stock solution by diluting each commercial formulation of pesticides in distilled water before the test and applying it to the soil during its 
moisture-correction procedure. The concentrations tested were determined based on values above and below those obtained with the commercially recommended doses of the products.

The concentration for the application of the product in its commercial recommendation was extrapolated from the values obtained by the multiplication of the recommended volume per hectare (ha), assuming soil density of $1 \mathrm{~g} \mathrm{~cm}^{-3}$ and $0.10 \mathrm{~m}$ deep layer $\left(\mathrm{Comet}^{\circledR}\right)$, and of the recommended volume per kilogram of seeds used per hectare (ha) (Standak ${ }^{\circledR} \mathrm{Top}$ ). For both products, soybean (Glycine max) was used as reference crop, and the amount of seeds per hectare was calculated considering inter-row spacing of $0.50 \mathrm{~m}$ and 12 seeds per linear meter $\left(50 \mathrm{~kg}\right.$ of seeds ha $\left.{ }^{-1}\right)$. These procedures followed the methodology described by Alves et al. (2013) and were used to determine the concentrations of the pre-tests of acute toxicity and subsequent calculation of the final concentrations tested.

Concentrations of $0.08,0.17,0.35,0.70,1.40$ and $2.80 \mathrm{mg}$ of the commercial formulation $\mathrm{kg}^{-1}$ soil were used for the fungicide and $0.05,0.10,0.20,0.60,1.20$ and $2.40 \mathrm{mg}$ of the commercial formulation $\mathrm{kg}^{-1}$ soil were used for the fungicide + insecticide. The predicted environmental concentrations of the active principles contained in the formulations of the pesticides are described in Table 1. The control treatment, which did not receive the products, had only its moisture corrected using deionized water.

Table 1. Description of the commercial formulations of the pesticides tested and their active ingredient (a.i.), and commercial doses for soybean crop.

\begin{tabular}{llcc}
\hline $\begin{array}{l}\text { Commercial } \\
\text { name }\end{array}$ & Active ingredient (a.i.) & $\begin{array}{c}\text { Quantity of a.i. } \\
\left(\mathrm{g} \mathrm{L}^{-1}\right)\end{array}$ & $\begin{array}{c}\text { Concentration at commercial dose } \\
\left(\mathrm{mg} \mathrm{a.i.}^{-1} \text { soil }\right)\end{array}$ \\
\hline $\begin{array}{l}\text { Comet }^{\circledR} \\
\text { Standak }\end{array}{ }^{\oplus}$ Top & $\begin{array}{l}\text { Pyraclostrobin } \\
\text { Pyraclostrobin + thiophanate- } \\
\text { methyl + fipronil }\end{array}$ & 500 & 0.0875 \\
\hline
\end{tabular}

\subsection{Chronic (survival and reproduction) toxicity test}

The effects of toxicity of the products tested on earthworms were evaluated according to the methods described by the protocols ISO 11268-1 (ISO, 1995) and ISO 11268-2 (ISO, 1998) by means of lethality and reproduction tests, respectively. The experiment was conducted under a completely randomized design with six (6) replicates. Each experimental unit consisted of plastic pots, which received $500 \mathrm{~g}$ of the artificial soil treated with the concentrations of the pesticides tested. Prior to exposure to pesticides, the earthworms were acclimated for $24 \mathrm{~h}$ in the TAS.

Ten adult and clitellated earthworms aged between 2 months and 1 year, with body weight between 250 and $600 \mathrm{mg}$, were placed in each pot. During the test period, soil moisture was corrected weekly and the organisms were fed at the beginning of the test and at a 14-day interval, with moist manure of equine with no history of medication use and diet based on pasture, sieved and defaunated by freeze-thaw cycles.

Lethality was evaluated through the reproduction tests. At 28 days after the beginning of the test, the earthworms of each experimental unit were withdrawn and counted for the number of survivors. In the experimental units, only the eggs and juveniles generated were kept incubated for more than 28 days for the reproduction test. After 56 days of testing, the sampling units were placed in a water bath at a temperature of $60^{\circ} \mathrm{C}$ for 60 minutes, so that the earthworms would move to the soil surface and the juveniles generated could be counted.

\subsection{Data analysis}

The results of survival, reproduction and biomass loss were tested for normality and homogeneity by the Kolmogorov-Smirnov and Levene tests, respectively. The data were subjected to analysis of variance (One-way ANOVA) and when there was statistical difference the means were compared by Dunnett Test $(\mathrm{p}<0.05)$. Biomass loss data were subjected to non- 
parametric analysis by applying the Kolmogorov-Smirnov test. EC50 values (estimated concentration to cause one or more specific effects capable of affecting 50\% of the organisms) were calculated using the Logistic model. NOEC (no observed effect concentration) and LOEC (lowest observed effect concentration) values were also determined. All analyses were performed using Statistica 7.0 software (StatSoft, 2004).

\section{RESULTS AND DISCUSSION}

Both tests met the validation criteria in the TAS in accordance with the respective ISO guidelines. The first stages of ecotoxicity analyses are carried out in the laboratory, where a range of concentrations of the chemical products (e.g., pesticides) can be available in an artificial substrate (ISO, 1998). In addition, for reasons of standardization and to facilitate comparison of results, most standardized tests using soil invertebrates were conducted in artificial soils (OECD, 1984). Alves and Cardoso (2016) have argued that studies using artificial soils provide information that can be internationally compared, while natural soils provide local information. Thus, artificial soil could be used in a first step and provide an international dataset about pesticide effects that have not yet been studied, and the researchers can decide if the risk is acceptable or not.

The concentrations of the commercial formulations of the pesticides with fungicide and fungicide + insecticide effects added to the TAS were not sufficient to affect the survival of $E$. andrei earthworms ( $\mathrm{p}>0.05)$ (Figure 1) and did not cause any percentage reduction in the biomass of these organisms (Figure 2).

The commercial formulations of the pesticides with fungicide effect containing pyraclostrobin and with fungicide + insecticide effect containing the mixture of pyraclostrobin + thiophanate-methyl + fipronil did not affect death rates of $E$. andrei earthworms and did not result in significant reduction of their body biomass at any of the tested concentrations added to the TAS. No studies were found evaluating the survival and reproduction toxicity of commercial formulations to E. andrei. However, data referring to the single active ingredients, according to the European Union, estimate concentrations capable of causing death of $50 \%$ of the organisms $\geq 567 \mathrm{mg} \mathrm{kg}^{-1}$ soil for the active principle pyraclostrobin at an exposure of 14 days, > $1000 \mathrm{mg} \mathrm{kg}^{-1}$ soil for fipronil and > $13.2 \mathrm{mg} \mathrm{kg}^{-1}$ soil for thiophanate-methyl (EC, 2004; 2005; 2011). Reductions in body biomass were observed after exposure to fipronil concentrations of $65.5 \mathrm{mg} \mathrm{kg}^{-1}$ soil in TAS (Alves et al., 2013). These concentrations, capable of causing lethal effect, are much higher than the equivalent amount of active ingredient present in concentrations of formulations evaluated in this study.

For other soil invertebrates, such as collembolans and enchytraeids, the active ingredient fipronil caused death of the organisms at concentrations from $0.3 \mathrm{mg} \mathrm{kg}^{-1}$ soil, and the toxicity varied between the natural and artificial soils, demonstrating higher toxicity potential in artificial soil (Zortéa et al., 2018). Although some studies report the absence of negative effects on the survival of organisms, this does not indicate that these pesticides do not pose a threat to the terrestrial ecosystem. For a long time, the toxicity effects of substances were estimated from lethality tests. However, currently the sublethal effects, evaluated through reproduction and biomass-loss tests, provide a more reliable diagnosis of the potential effect of contaminants. Effects on reproduction and growth rates may be more sensitive than survival to assess the environmental risk of certain substances (Reinecke and Reinecke, 2007; Wang et al., 2015). 


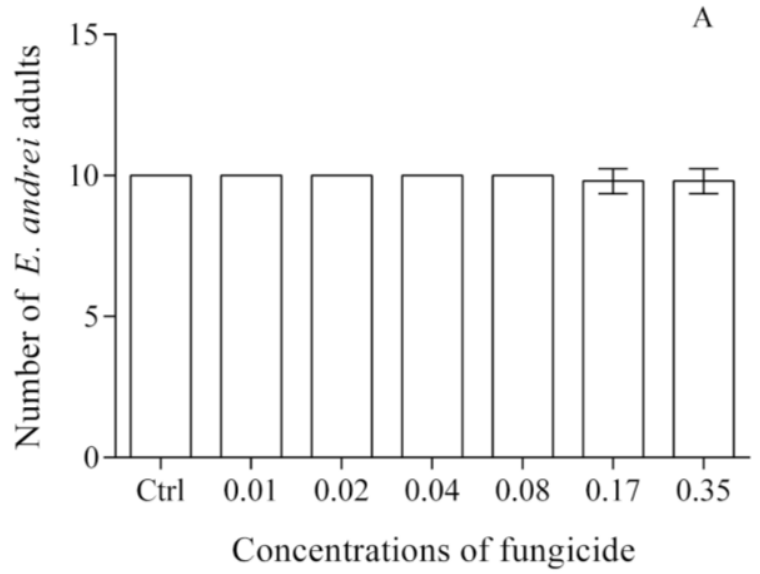

$\left(\mathrm{mg} \mathrm{kg}^{-1}\right)$

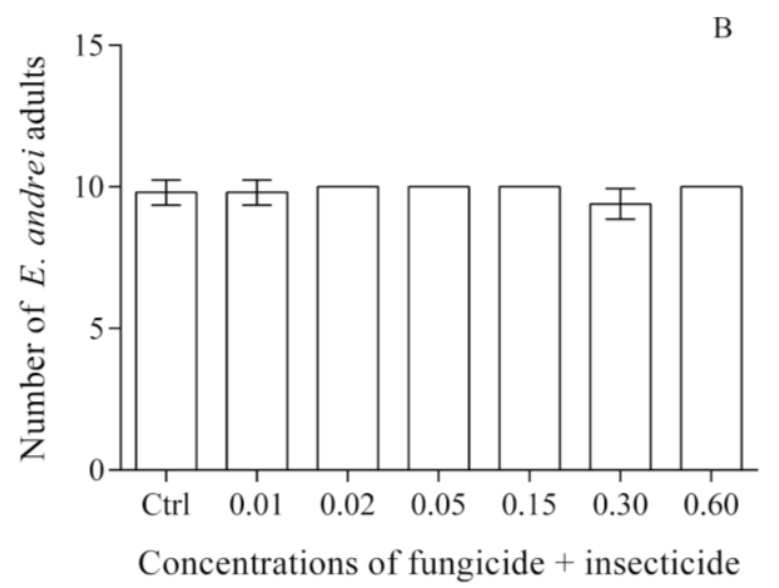

$\left(\mathrm{mg} \mathrm{kg}^{-1}\right)$

Figure 1. Average number of live E. andrei adults at 28 days in Tropical Artificial Soil (TAS) treated with concentrations of fungicide $(A)$ and fungicide + insecticide $(B) .(T)$ Standard deviation $(n=6)$.
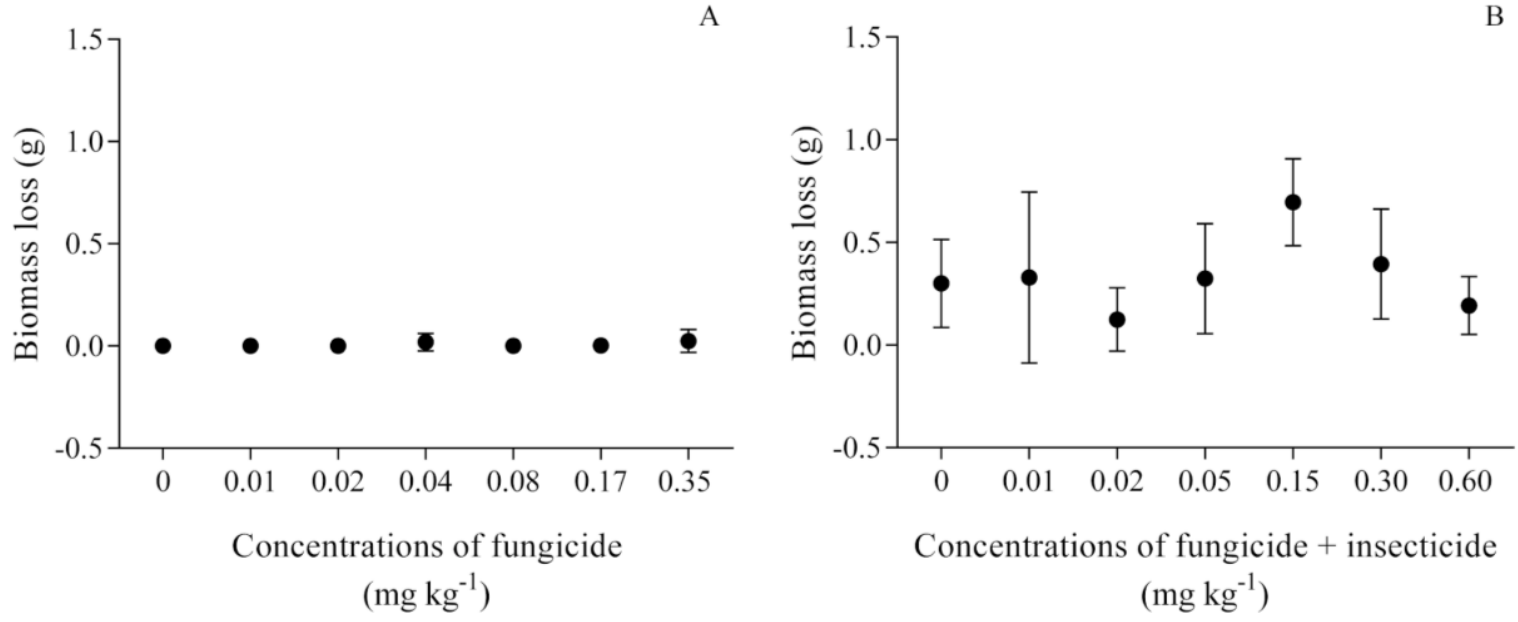

Figure 2. Biomass of $E$. andrei at 28 days in Tropical Artificial Soil (TAS) treated with concentrations of fungicide (A) and fungicide + insecticide $(B) .(T)$ Standard deviation $(n=5)$.

The number of juveniles produced by $E$. andrei was significantly affected $(\mathrm{p}<0.05)$ by the concentrations of both commercial formulations of pesticides, fungicide and fungicide + insecticide, containing the active principles pyraclostrobin and pyraclostrobin + thiophanatemethyl + fipronil after 56 days of exposure. In the fungicide tests, there was a reduction in the number of juveniles at concentrations from $0.08 \mathrm{mg} \mathrm{kg}^{-1}$ soil (LOEC), with NOEC values lower than $0.08 \mathrm{mg} \mathrm{kg}^{-1}$ (Figure 3). For the fungicide + insecticide tests, there was a significant reduction in the number of juveniles at concentrations from $0.05 \mathrm{mg} \mathrm{kg}^{-1}$ soil (LOEC), with NOEC values lower than $0.05 \mathrm{mg} \mathrm{kg}^{-1}$. EC50 value was equal to $4.51 \mathrm{mg} \mathrm{kg}^{-1}$ soil $(<0.05-$ 20.94), respectively. The EC50 values and the respective confidence intervals for the tests with the fungicide formulation could not be calculated.

Although the concentrations of the commercial formulations of the pesticides tested did not cause death of the exposed organisms, they were able to reduce the reproduction rate of $E$. andrei. The effects of the exposure of earthworms to the fungicide containing the active ingredient pyraclostrobin could be observed at low concentrations, demonstrating the toxicity of this substance to the species. Effects of pyraclostrobin on E. fetida were also studied by Ma et al. (2019), who observed oxidative damage at concentrations from $0.1 \mathrm{mg} \mathrm{kg}^{-1}$ soil and DNA damage when earthworms were exposed to concentrations of 1.0 and $2.5 \mathrm{mg} \mathrm{kg}^{-1}$ soil. Other 
fungicides belonging to the same chemical group of pyraclostrobin, the strobilurins, were able to cause subchronic effects. The fungicide fluoxastrobin caused DNA damage and induced oxidative stress in E. fetida earthworms at concentrations between 0.1 and $2.5 \mathrm{mg} \mathrm{kg}^{-1}$ soil (Zhang et al., 2018).

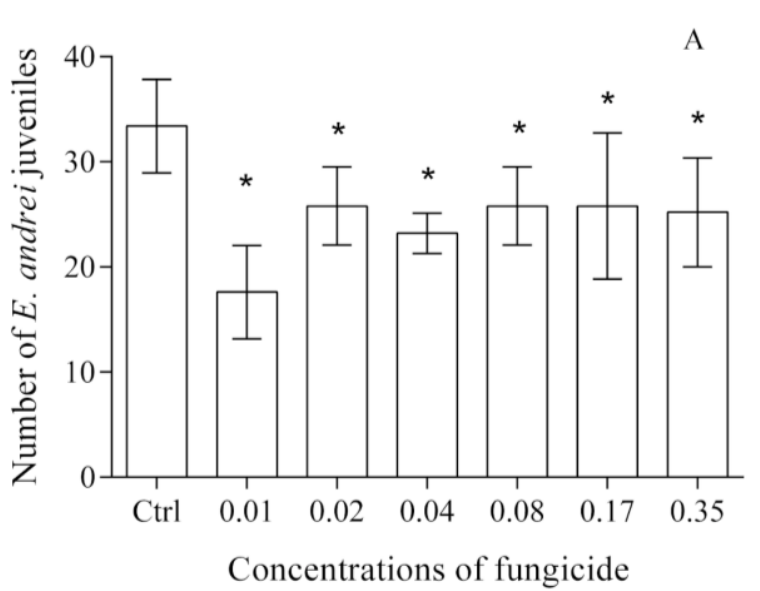

$\left(\mathrm{mg} \mathrm{kg}^{-1}\right)$

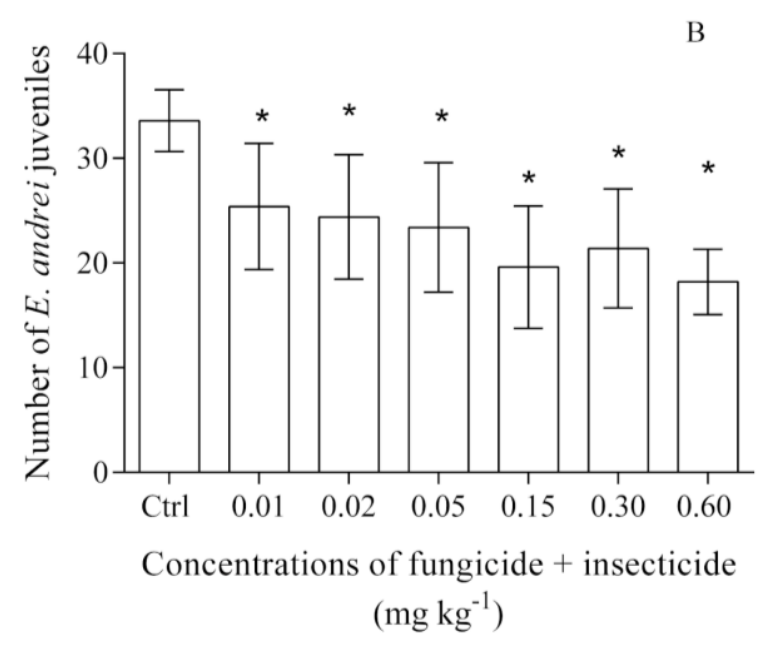

$\left(\mathrm{mg} \mathrm{kg}^{-1}\right)$

Figure 3. Average number of E. andrei juveniles found in Tropical Artificial Soil (TAS) treated with fungicide (A) and fungicide + insecticide (B) concentrations after 56 days. Asterisks $(*)$ indicate a significant reduction in the number of juveniles compared to the control $(\mathrm{p}<0.05)$ by the Dunnett test. $(\mathrm{T})$ Standard deviation $(\mathrm{n}=6)$.

The commercial formulation of the pesticide with fungicide + insecticide effects containing the mixture of active ingredients, pyraclostrobin + thiophanate-methyl + fipronil, caused reduction in the reproduction rates of $E$. andrei from the first concentration tested, 0.05 $\mathrm{mg} \mathrm{kg}^{-1}$ soil. Studies evaluating the toxicity of fipronil on the reproduction of $E$. andrei estimated NOEC of $5 \mathrm{mg} \mathrm{kg}^{-1}$ and LOEC of $10 \mathrm{mg} \mathrm{kg}-1$ (Zortéa et al., 2018) and significant reduction in reproduction rates at concentration of $62.50 \mathrm{mg} \mathrm{kg}-1$ (Alves et al., 2013) in TAS. Such concentrations are much higher than the concentrations of the active ingredient fipronil, even at the highest concentrations tested in the present study. At the highest concentration of the fungicide + insecticide formulation, which contains the mixture of active ingredients, including fipronil, this active ingredient corresponds to $0.15 \mathrm{mg} \mathrm{kg}-1$ soil. In view of the results obtained, in which the reduction in reproduction rate was observed even at low concentrations of the fungicide + insecticide formulation, this response may be related to the mixture of the active ingredients, as the interaction between them may lead to greater toxicity of the substances (Yang et al., 2017) or even to a high sensitivity to the active ingredient pyraclostrobin, present in both formulations, observed in the evaluation of Comet ${ }^{\circledR}$.

The mixture of active ingredients found in commonly marketed formulations and the synergistic effect of the multiple mixtures needs to be better explored (Yang et al., 2017). Yang et al. (2017) observed that the presence of several pesticides in the soil may increase the toxicity of the substances, causing greater risks to the soil ecosystem than expected for the single substances. The final effect of toxicity and interactions between the substances depends on the mixtures, even if the molecules present in the formulations have the same mode of action (Koutsaftis and Aoyama, 2007). Pesticides are intensely and inadequately used in many agricultural areas, contributing to a high concentration in the soil (Nunes and Espíndola, 2012).

Although subchronic effects of the active ingredient pyraclostrobin have already been evaluated, there are still no other studies evaluating its chronic effects on the reproductive rates of earthworms, not even of thiophanate-methyl. For EC50 values, the European Union considers concentrations capable of causing effect on reproductive rates in earthworms greater than $0.443 \mathrm{mg} \mathrm{kg}^{-1}$ soil, $0.85 \mathrm{mg} \mathrm{kg}^{-1}$ soil and $500 \mathrm{mg} \mathrm{kg}^{-1}$ soil for pyraclostrobin, thiophanate- 
methyl and fipronil, respectively (EC, 2004; 2005; 2011). The EC50 value found in the present study for the commercial formulation of the fungicide + insecticide was $4.51 \mathrm{mg} \mathrm{kg}^{-1}$ soil (< 0.05-20.94), respectively.

These active ingredients are included in low- and moderate-risk categories for earthworms. Although the classification does not indicate high risk and the exposure to the products tested in the present study did not cause immediate death of exposed earthworms, effects of reduction in the reproductive rates of this species were observed even at the lowest concentration tested. The reduction observed in the reproduction of the organisms may be associated with a reduction in the number of eggs (Gomez-Eyles et al., 2009). Considering the environmental exposure of these organisms to these substances in the long term, their permanence and life cycle in the soil may be threatened. Pyraclostrobin, thiophanate-methyl and fipronil had half-life values (DT50) of 12-101 days, 0.48-074 days and 120-308 days (EC, 2004; 2005; 2011) and may have a cumulative effect on the soil, especially because the products are often reapplied on the same crop, so these substances may reach high concentrations.

In the soil ecosystem, there are many organisms that perform important ecosystem services and guarantee the quality of the soil and yield in agricultural environments, promoting greater diversity in natural environments and the necessary conditions for ecological resilience (Sánchez-Bayo, 2011). Pesticides, as well as fungicides and insecticides, are harmful to earthworms and affect nutrient cycling, consequently affecting soil fertility. When adsorbed to organic material, these substances can still be available for earthworms and other soil organisms for many years after application in the field, prolonging the period of exposure of such organisms to these substances (Sánchez-Bayo, 2011). Adverse effects on earthworms may indirectly affect plant growth, because these organisms enrich the soil with macronutrients, providing nutrients such as phosphorus, potassium and especially nitrogen, which are essential for plant species (Fusaro et al., 2018).

Although subchronic effects of the active ingredient pyraclostrobin have already been evaluated, no other studies were found evaluating its chronic effects on earthworms, nor even survival and reproduction effects of the commercial formulations of fungicide and fungicide + insecticide, containing the active ingredients pyraclostrobin, thiophanate-methyl and fipronil. Considering the high toxicity potential of the tested substances found in the present study, especially pyraclostrobin, the studies should be extended to natural soils for a greater assessment of the environmental impact of these substances when applied to the field, because the toxicity of the molecule may still vary between natural and artificial soils, as it is directly related to their physicochemical characteristics, high clay contents, organic matter and cation exchange capacity, affecting the adsorption capacity of pollutants and bioavailability of pesticides (Zortéa et al., 2018).

From the data obtained in the present study, it was possible to see that the effects of the products tested at chronic levels are noted at low concentrations equivalent to the doses recommended for field applications in soil, putting earthworms and other soil organisms in danger.

\section{CONCLUSIONS}

The organisms of the species E. andrei were sensitive to both tested substances. Although the concentrations of the products did not affect the death rate, they were able to cause a reduction in the reproduction of these organisms, even at the lowest concentrations tested. However, other non-target organisms may be more sensitive to these products and there is a need to improve these data, including more species, such as plants, invertebrates, and microorganisms, even aquatic organisms. These results highlight the harmful effects of the use of these products, considering that earthworms and other organisms present in the terrestrial 
ecosystem play a key role in nutrient cycling and organic matter decomposition and may be exposed to concentrations equivalent to those tested in the present study, due to the inadequate and repeated application of the fungicide and fungicide + insecticide formulations based on pyraclostrobin, thiophanate-methyl and fipronil.

\section{ACKNOWLEDGEMENTS}

The authors thank the Coordination for the Improvement of Higher Education Personnel (CAPES) for granting the scholarship to the first author, the Regional Community University of Chapecó (UNOCHAPECÓ) for granting the scientific initiation scholarship to the second author and providing financial support. D.B. thanks National Council for Scientific and Technological Development $(\mathrm{CNPq})$ for the Research Productivity Grant (Process Number 305939/2018-1).

\section{REFERENCES}

ALVES, P. R. L.; CARDOSO, E. J. B. N. Overview of the Standard Methods for Soil Ecotoxicology Testing. In: LARRAMENDY, M.; SOLONESKY, S. (ed.). Invertebrates: Experimental Models in Toxicity Screening. Rijeka: InTech, 2016. p. 3556. http://dx.doi.org/10.5772/62228

ALVES, P. R. L.; CARDOSO, E. J. B. N.; MARTINES, A. M.; SOUSA, J. P.; PASINI, A. Earthworm ecotoxicological assessments of pesticides used to treat seeds under tropical $\begin{array}{llllll}\text { conditions. Chemosphere, } 2013 . & \text { v. 90, p. 2674-2682, }\end{array}$ http://dx.doi.org/10.1016/j.chemosphere.2012.11.046

BRASIL. Ministério da Agricultura, Pecuária e Abastecimento. AGROFIT. Sistemas de agrotóxicos fitossanitários. 2020. Available at: http://agrofit.agricultura.gov.br/agrofit_cons/principal_agrofit_cons. Access: Jan. 2020.

CARNEIRO, F.; RIGOTTO, R. M.; AUGUSTO, L. G.; FRIEDRICH, K. K.; BÚRIGO, A. C. Dossiê ABRASCO: um alerta sobre os impactos dos agrotóxicos na saúde. Rio de Janeiro: EPSJV; São Paulo: Expressão Popular, 2015.

CARRIGER, J. F.; RAND, G. M.; GARDINALI, P. R.; PERRY, W. B.; TOMPKINS, M. S.; FERNANDEZ, A. M. Pesticides of potential ecological concern in sediment from South Florida canals: an ecological risk prioritization for aquatic arthropods. Soil and Sediment Contamination, v. 15, p. 21-45, 2006. http://dx.doi.org/10.1080/15320380500363095

CHEVILlOT, F.; CONVERT, Y.; DESROSIERS, M.; CADORET, N.; VEILLEUX, É.; CABANA, H.; BELLENGER, J.-P. Selective bioaccumulation of neonicotinoids and sub-lethal effects in the earthworm Eisenia andrei exposed to environmental concentrations in an artificial soil. Chemosphere, v. 186, p. 839-847, 2017. http://dx.doi.org/10.1016/j.chemosphere.2017.08.046

EC. Review report for the active substance pyraclostrobin. Finalised in the Standing Committee on the Food Chain and Animal Health at its meeting on 28 November 2003 in view of the inclusion of pyraclostrobin in Annex I of Council Directive 91/414/EEC. SANCO/1420/2001-Final. 08 September 2004. Available at: http://ec.europa.eu/food/plant/pesticides/eu-pesticidesdatabase/public/?event=activesubstance. ViewReview\&id=379 Access: January 2020. 
EC. Review report for the active substance thiophanate-methyl. Finalised in the Standing Committee on the Food Chain and Animal Health at its meeting on 15 February 2005 in view of the inclusion of thiophanate-methyl in Annex I of Directive 91/414/EEC. 5030/VI. 2005. Available at: http://ec.europa.eu/food/plant/pesticides/eu-pesticidesdatabase/public/?event=activesubstance.ViewReview\&id=187 Access: January 2020.

EC. Fipronil, product-type PT18 (insecticides, acaricides and products to control other arthropods). Finalised in the Standing Committee on Biocidal Products at its meeting on 6th May 2011 in view of its inclusion in Annex I to Directive 98/8/EC. 2011. Available at: $\quad$ http://dissemination.echa.europa.eu/Biocides/ActiveSubstances/0033-18/003318_Assessment_Report.pdf Access: January 2020.

EMBRAPA. Manual de métodos de análise de solo. 2. ed. Rio de Janeiro, 2011.

FAO. FAOSTAT: Food and agriculture data. 2019. Available at: http://www.fao.org/faostat/en/\#data/EP/visualize. Access: January 2020.

FUSARO, S.; GAVINELLI, F.; LAZZARINI, F.; PAOLETTI, M. G. Soil Biological Quality Index based on earthworms (QBS-e). A new way to use earthworms as bioindicators in agroecosystems. Ecological Indicators, v. 93, p. 1276-1292, 2018. http://dx.doi.org/10.1016/j.ecolind.2018.06.007

GARCIA, M. V. B. Effects of pesticides on soil fauna: development of ecotoxicological test methods for tropical regions. 2004. 281p. Thesis (Doctor of Agricultural Science) University of Bonn, Bonn, 2004.

GOMEZ-EYLES, J. L.; SVENDSEN, C.; LISTER, L.; MARTIN, H.; HODSON, M. E.; SPURGEON, D. J. Measuring and modelling mixture toxicity of imidacloprid and thiacloprid on Caenorhabditis elegans and Eisenia fetida. Ecotoxicology and $\begin{array}{llllll}\text { Environmental Safety, } & \text { v. } & 72, & \text { p. } & 71-79, & \end{array}$ http://dx.doi.org/10.1016/j.ecoenv.2008.07.006

IBAMA. Boletins anuais de produção, importação, exportação e vendas de agrotóxicos no Brasil. 2019. Available at: https://www.ibama.gov.br/agrotoxicos/relatorios-decomercializacao-de-agrotoxicos. Access: Jan. 2020.

ISO. Soil quality - Determination of effects on lethality (Eisenia andrei) by soil pollutants. ISO 11268-1. Genève, 1995.

ISO. Soil quality - Effects of pollutants on earthworms (Eisenia fetida) - Part 2: Determination of effects on reproduction. ISO 11268-2. Genève, 1998.

KOUTSAFTIS, A.; AOYAMA, I. Toxicity of four antifouling biocides and their mixtures on the brine shrimp Artemia salina. Science of The Total Environment, v. 387, p. 166174, 2007. http://dx.doi.org/10.1016/j.scitotenv.2007.07.023

MA, J.; CHENG, C.; DU, Z.; LI, B.; WANG, JINHUA; WANG, JUN; WANG, Z.; ZHU, L. Toxicological effects of pyraclostrobin on the antioxidant defense system and DNA damage in earthworms (Eisenia fetida). Ecological Indicators, v. 101, p. 111-116, 2019. http://dx.doi.org/10.1016/j.ecolind.2019.01.015

NITI, C.; SUNITA S.; KAMLESH, K.; RAKESH, K. Bioremediation: An emerging technology for remediation of pesticides. Research Journal of Chemistry and Environment, v. 7, p. 88-105. 2013. 
NUNES, M. E. T.; ESPÍNDOLA, E. L. G. Sensitivity of Eisenia andrei (Annelida, Oligochaeta) to a commercial formulation of abamectin in avoidance tests with artificial substrate and natural soil under tropical conditions. Ecotoxicology, v. 21, p. 1063-1071, 2012. http://dx.doi.org/10.1007/s10646-012-0859-6

OECD. Guidelines for testing of chemicals. Test $n^{\circ}$ 207: Earthworm, Acute Toxicity Tests. Paris: OECD Publishing, 1984.

PITOMBEIRA DE FIGUEIRÊDO, L.; DAAM, M. A.; MAINARDI, G.; MARIËN, J.; ESPÍNDOLA, E. L. G.; GESTEL, C. A. M. VAN; ROELOFS, D. The use of gene expression to unravel the single and mixture toxicity of abamectin and difenoconazole on survival and reproduction of the springtail Folsomia candida. Environmental Pollution, v. 244, p. 342-350, 2019. http://dx.doi.org/10.1016/j.envpol.2018.10.077

REINECKE, S. A.; REINECKE, A. J. The impact of organophosphate pesticides in orchards on earthworms in the Western Cape, South Africa. Ecotoxicology and Environmental Safety, v. 66, p. 244-251, 2007. http://dx.doi.org/10.1016/j.ecoenv.2005.10.006

RICO, A.; SABATER, C.; CASTILLO, M.-Á. Lethal and sub-lethal effects of five pesticides used in rice farming on the earthworm Eisenia fetida. Ecotoxicology and Environmental Safety, v. 127, p. 222-229, 2016. http://dx.doi.org/10.1016/j.ecoenv.2016.02.004

SÁNCHEZ-BAYO, F. Impacts of agricultural pesticides on terrestrial ecosystems. In: SÁNCHEZ-BAYO, F.; BRINK, P. VAN DEN; MANN, R. (Eds.). Ecological Impacts of Toxic Chemicals. [S.1.] Bentham Science Publishers, 2011. p. 63-87. http://dx.doi.org/10.2174/978160805121210063

SÁNCHEZ-BAYO, F.; GOULSON, D.; PENNACCHIO, F.; NAZZI, F.; GOKA, K.; DESNEUX, N. Are bee diseases linked to pesticides? - A brief review. Environment International, v. 89-90, p. 7-11, 2016. http://dx.doi.org/10.1016/j.envint.2016.01.009

STATSOFT INC. STATISTICA (data analysis software system). Tulsa, 2004.

TEDESCO, M. J.; GIANELLO, C.; BISSANI, C. A.; VOLKWEISS, S. J. Análises de Solo, Plantas e Outros Materiais. Porto Alegre: Universidade Federal do Rio Grande do Sul, 1995.

WANG, K.; PANG, S.; MU, X.; QI, S.; LI, D.; CUI, F.; WANG, C. Biological response of earthworm, Eisenia fetida, to five neonicotinoid insecticides. Chemosphere, v. 132, p. 120-126, 2015. http://dx.doi.org/10.1016/j.chemosphere.2015.03.002

YANG, G.; CHEN, C.; WANG, Y.; PENG, Q.; ZHAO, H.; GUO, D.; WANG, Q.; QIAN, Y. Mixture toxicity of four commonly used pesticides at different effect levels to the epigeic earthworm, Eisenia fetida. Ecotoxicology and Environmental Safety, v. 142, p. 29-39, 2017. http://dx.doi.org/10.1016/j.ecoenv.2017.03.037

ZHANG, C.; ZHU, L.; WANG, JUN; WANG, JINHUA; DU, Z.; LI, B.; ZHOU, T.; CHENG, C.; WANG, Z. Evaluating subchronic toxicity of fluoxastrobin using earthworms (Eisenia fetida). Science of The Total Environment, v. 642, p. 567-573, 2018. http://dx.doi.org/10.1016/j.scitotenv.2018.06.091

ZORTÉA, T.; SILVA, A. S.; REIS, T. R.; SEGAT, J. C.; PAUlinO, A. T.; SOUSA, J. P.; BARETTA, D. Ecotoxicological effects of fipronil, neem cake and neem extract in edaphic organisms from tropical soil. Ecotoxicology and Environmental Safety, v. 166, p. 207-214, 2018. http://dx.doi.org/10.1016/j.ecoenv.2018.09.061 